\title{
Ubaldo Castagnoli e la piscina pensile del Palazzo dei Telefoni di Torino
}

\author{
Manuela Incerti \\ Gianmarco Mei \\ Anna Castagnoli
}

Abstract

Nei primi anni Quaranta viene inaugurata a Torino una piscina scoperta all'ultimo piano del nuovo edificio della STIPEL, luogo di svago per i dipendenti della società telefonica. Progettista è Ubaldo Castagnoli, giovane architetto-ingegnere, fondatore - insieme a Luigi Figini, Gino Pollini, Guido Frette Sebastiano Larco, Carlo Enrico Rava, Giuseppe Terragni - del Gruppo 7. Attraverso l'analisi dei disegni di archivio inediti e la modellazione digitale prosegue il recente lavoro di indagine su questo autore ancora non adeguatamente esplorato.

\section{Parole chiave}

Gruppo 7, piscine, disegni di archivio, ricostruzioni digitali, Ubaldo Castagnoli.

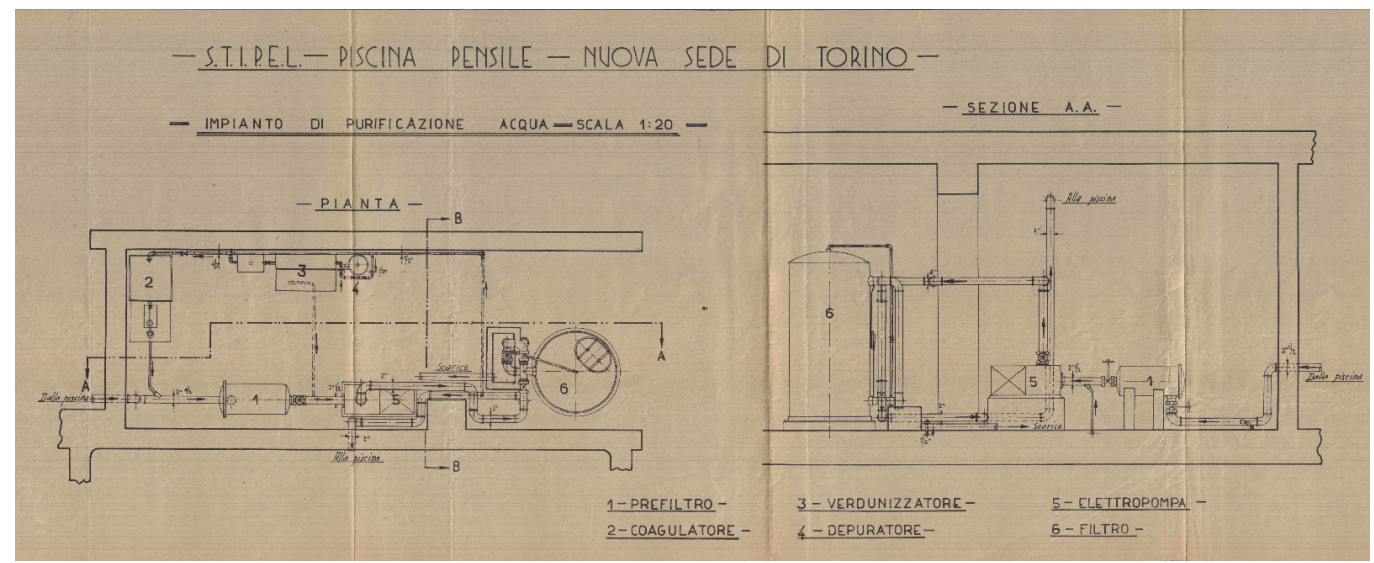




\section{Note storiche}

Ubaldo Castagnoli (Roma 1902 - Torino 1982) si laurea nel 1925 presso il Regio Istituto tecnico superiore di Milano dove conosce i giovani sei colleghi del Gruppo 7. Come è noto, la sua adesione al gruppo ebbe breve e fu subito sostituito da Adalberto Libera.

Dal 1927 fino ai primi anni del 1930 condivide lo studio insieme a Guido Frette, in Via Rugabella 9 a Milano. Iscritto all'Ordine Interprovinciale della Lombardia e degli Architetti di Milano (29/09/1928) firma insieme a Frette una tomba per il cimitero israelitico di Milano [1929, Archivio Figini-Pollini, MART, fig. Pol.3.I .2.2] e il negozio per Sartoria Spagnolini in via Manzoni 7 a Milano (fig. I). La collaborazione con Frette si interruppe in seguito all'assunzione presso la Società Telefonica STIPEL per la quale lavorerà come ingegnere di centrali elettriche e telefoniche per l'area Piemonte e Lombardia fino al 1957; a causa di alcuni problemi di salute continuerà a collaborare per altri sette anni con la STIPEL come libero professionista [I]. (A.C.).

\section{L'edificio dei telefoni e le sue vicende storiche}

L'isolato delimitato dalle vie Antonio Meucci, Luigi Mercantini, Davide Bertolotti e Confienza, ospitava dal 1925 gli uffici della società STIPEL, concessionaria del servizio telefonico per la zona del Piemonte e della Lombardia. Gli archivi del Comune diTorino ci consentono di ricostruire alcuni passaggi che portarono alla sopraelevazione dell'edificio storico e ad una nuova addizione sul fronte di via Meucci. Le vicende principali si svolsero tra il 1936 e il 1950 e furono sempre a firma dell'architetto Castagnoli.

Le crescenti esigenze di spazio portarono inizialmente ad una richiesta di ampliamento sul lato di via Confienza (1936) per poi giungere, all'inizio del 1939, al progetto della nuova sede su via Meucci oggetto di alcune varianti (fig. 2) sino al 1943 [2]. Negli anni della Seconda Guerra Mondiale Torino fu spesso flagellata da numerose incursioni aeree che colpirono molte volte, tra il novembre 1942 e l'agosto 1943, anche il palazzo dei Telefoni.

In un momento complesso come quello bellico nasce il progetto della nuova sede organizzata su 7 piani, più due sotterranei, compreso il ricovero antiaereo (1939) con dimensioni di $61,40 \times 28,15$ metri. Nel luglio 1940 viene presentato il primo progetto per una piscina sul tetto, sottoposto poi a variante nel 1942. Di grande interesse sono gli elaborati in cui Casta-

Fig. I. Disegno dell'arredo per la sartoria. Elaborato non firmato e dunque non univocamente due autori. Entrambi gl architetti realizzavano prospettive con quo prospettive con questo punto di vista [Castagnoli, punto di vista
Frette 1934]

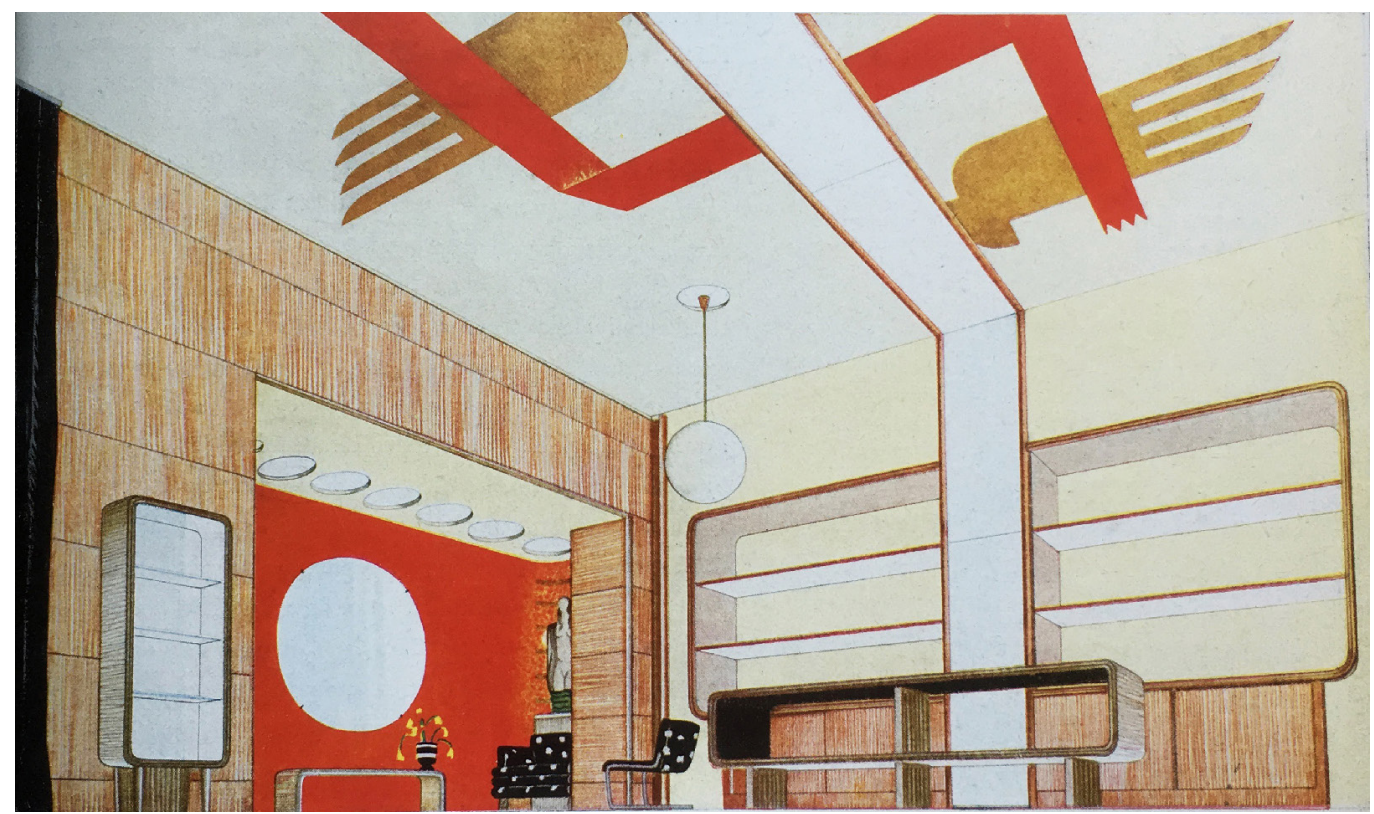


Fig. 2. A sinistra l'edificio del 1925, a destra l'edificio originario con la sopraelevazione e la nuova addizione su via Meucci entrambe a firm di Castagnoli (a destra
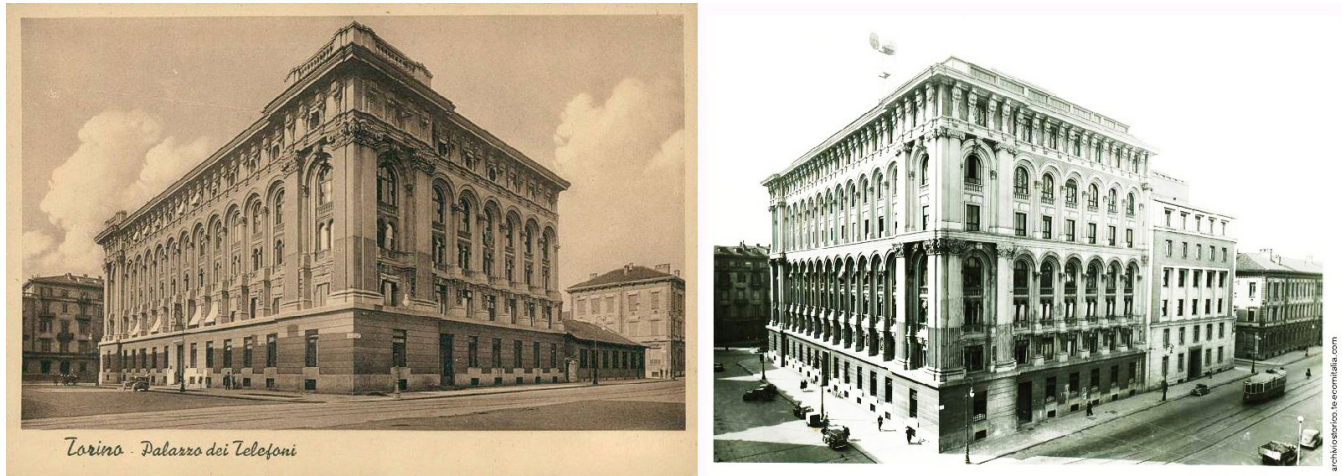

gnoli affronta il problema compositivo della relazione tra i due corpi di fabbrica: l'esistente, chiaramente caratterizzato da importanti dettagli di tipo storico, e il suo nuovo edificio contraddistinto da linee pulite e rigorosa geometria (fig. 3).

II suo approccio progettuale, rispettoso delle forme storiche, è ben leggibile nel bel disegno del 1950, che vede a sua firma la progettazione del secondo ordine gigante dell'edificio su via Confienza, scrupolosamente raccordato con la quota della nuova piscina. (M.I.).

\section{La piscina pensile}

Gli elaborati di progetto della piscina sul tetto del nuovo edificio presentati nel febbraio del 1942 andarono a sostituire i disegni del 1940.

Si tratta indubbiamente di un progetto molto innovativo sia dal punto di vista sociale (gli spazi erano destinati ai dipendenti STIPEL per i momenti di svago del dopolavoro), che dal punto di vista progettuale. Pochi anni prima Enrico del Debbio aveva pubblicato un pregevole volume intitolato Piscine [Del Debbio 1933] in cui venivano descritti, con materiale grafico e fotografico, i più interessanti e importanti progetti internazionali di piscine, suddivisi per tipologie e usi. Nel libro non solo non sono presenti

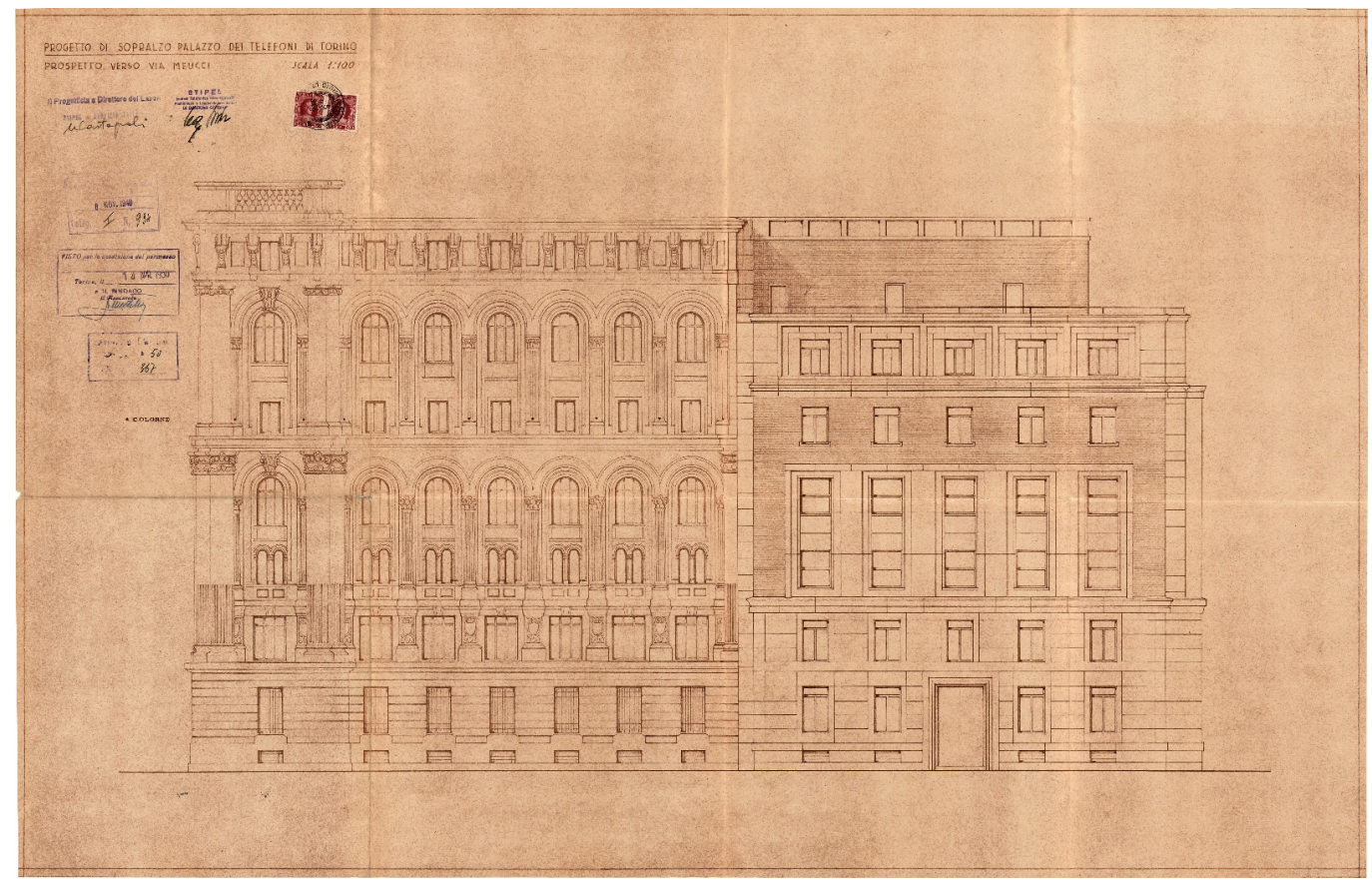


vasche sul tetto, ma pochissime sono quelle non 'contro-terra'. Un'altra possibile fonte a disposizione di Castagnoli era indubbiamente il Manuale dell'Architetto del Donghi [Donghi 1923] che, pur dedicando diverse decine di pagine a questo tema progettuale, contiene rari riferimenti alle vasche poste ad una certa distanza dal terreno con 'camera d'aria' esterna. L'idea di Castagnoli fu dunque originale (per la piccola e poco profonda vasca di Le Corbusier sul tetto dell'Unitè d'Abitation di Marsiglia, occorre aspettare gli anni ‘50): una vasca a 32 metri di altezza con una splendida vista sul panorama torinese (fig. 4).

Come per il progetto della Centrale di Città Studi di Milano [Velo 2020], i rivestimenti della piscina sono attentamente disegnati con ricorsi orizzontali e verticali di piastrelle rettangolari. Sono presenti infine anche gli elaborati costruttivi degli impianti idraulico, di depurazione e la descrizione del corridoio di ronda per l'ispezione della vasca sospesa da lui titolata 'pensile' (fig. 5).

A completamento dell'indagine sulla forma e sugli aspetti percettivi della fruizione di questo spazio oggi non più in funzione [3] interviene la ricostruzione digitale tridimensionale: il ridisegno del progetto dell'intero edificio. Si tratta di una metodica oramai ampiamente consolidata nel settore scientifico disciplinare, già esplorata dal gruppo di ricerca, nella sua valenza sia di strumento di studio, sia di opportunità di valorizzazione e divulgazione del tema del progetto architettonico non costruito o distrutto a causa di eventi che si sono succeduti nel tempo [4] (M.I.).

\section{II modello digitale tridimensionale}

Come parte integrante del percorso di conoscenza del Palazzo dei telefoni è stato costruito un modello digitale a partire dai disegni originali.

Il modello è stato realizzato con un software di modellazione di superfici NURBS in ambito didattico [5]. II processo di modellazione risulta essere un utile strumento di indagine ed analisi.

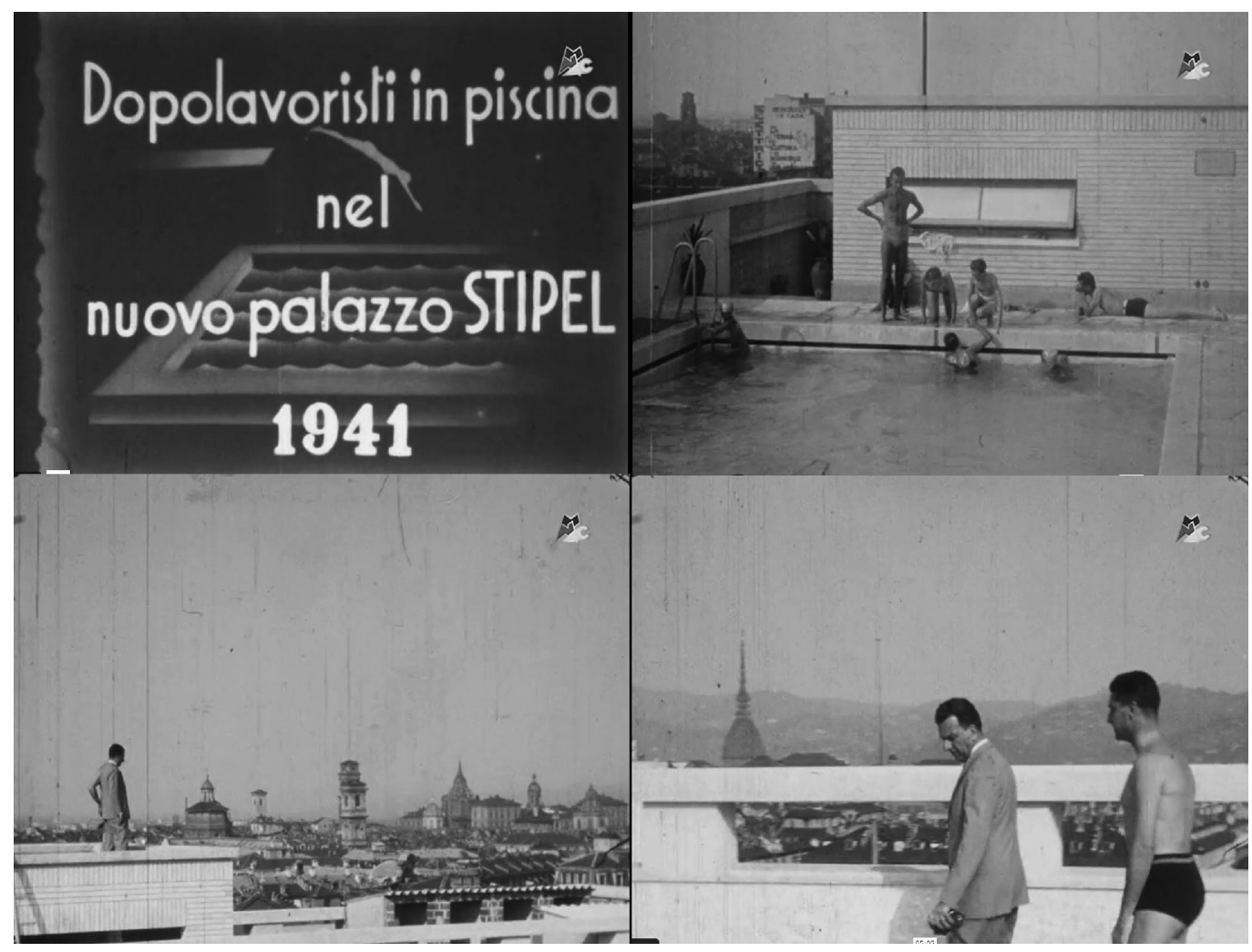


Fig. 5. Elaborato a firma ell architetto Castagno "Piscina pensile sul (Archivio EdificaTO).

Fig. 6. Sezioni trasversali e longitudinali dell'edificio, a firma dell'architetto

Castagnoli, 1942

(Archivio EdificaTO).

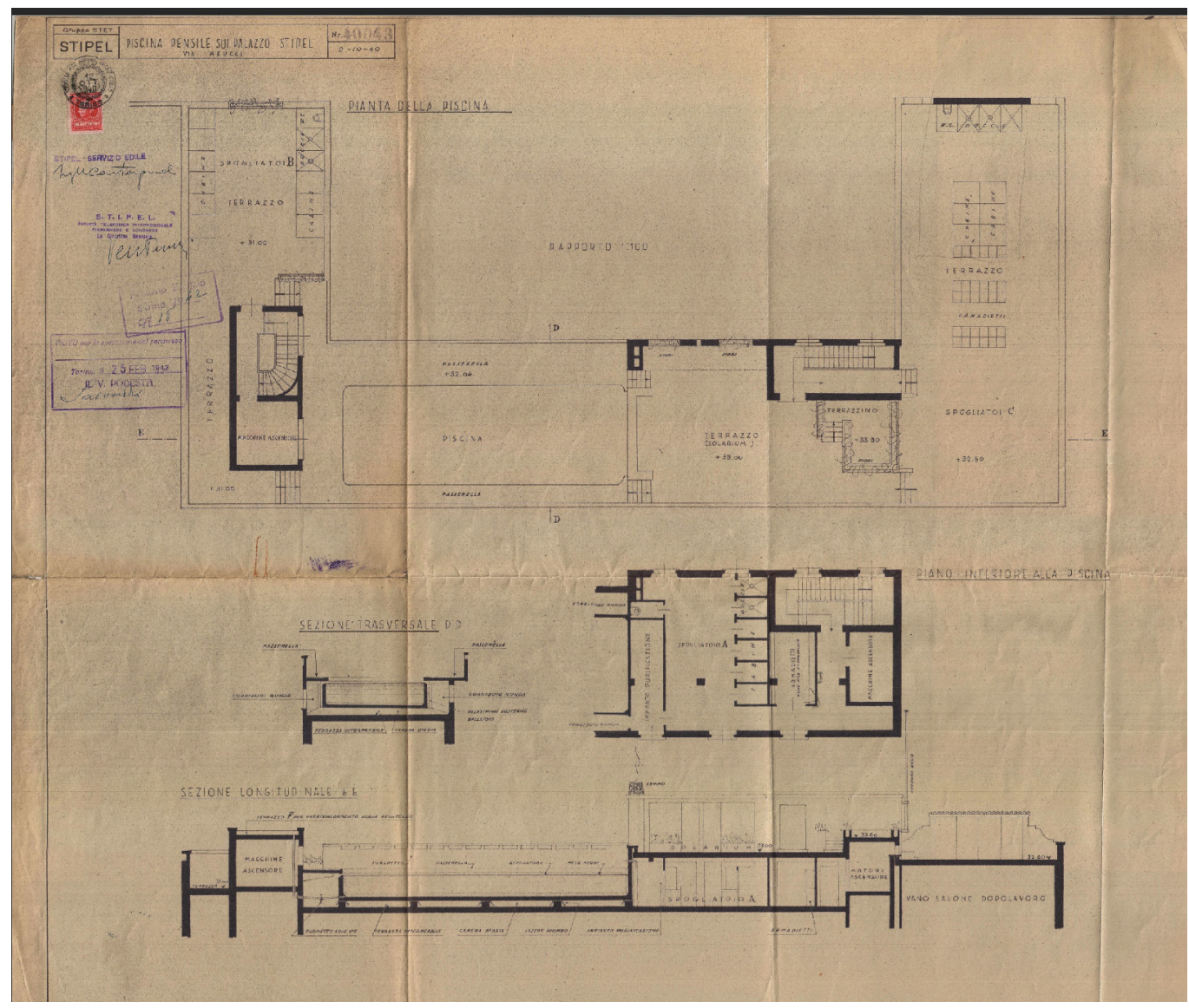

Le tecniche di modellazione 3D di un oggetto includono infatti due principali fasi: la fase analitica (raccolta del materiale di base, calcolo delle dimensioni e dei parametri) e quella prettamente di modellazione [Hevko 2020, p. 2]. La riproduzione tridimensionale, quindi, presuppone uno sforzo di comprensione spaziale, anche delle parti più articolate dell'edificio, come gli ultimi piani in cui si susseguono doppi volumi ed interpiani variabili. La morfologia di questi ambienti non è immediatamente evidente dai disegni originali (fig. 6) e la modellazione implica di riportare a sistema, in maniera coerente, le informazioni geometriche e dimensionali reperibili da diversi elaborati d'archivio. Il modello ottenuto risulta poi essere un importante strumento di comunicazione, poiché permette di realizzare elaborati in grado di mostrare efficacemente queste articolazioni (fig. 7).

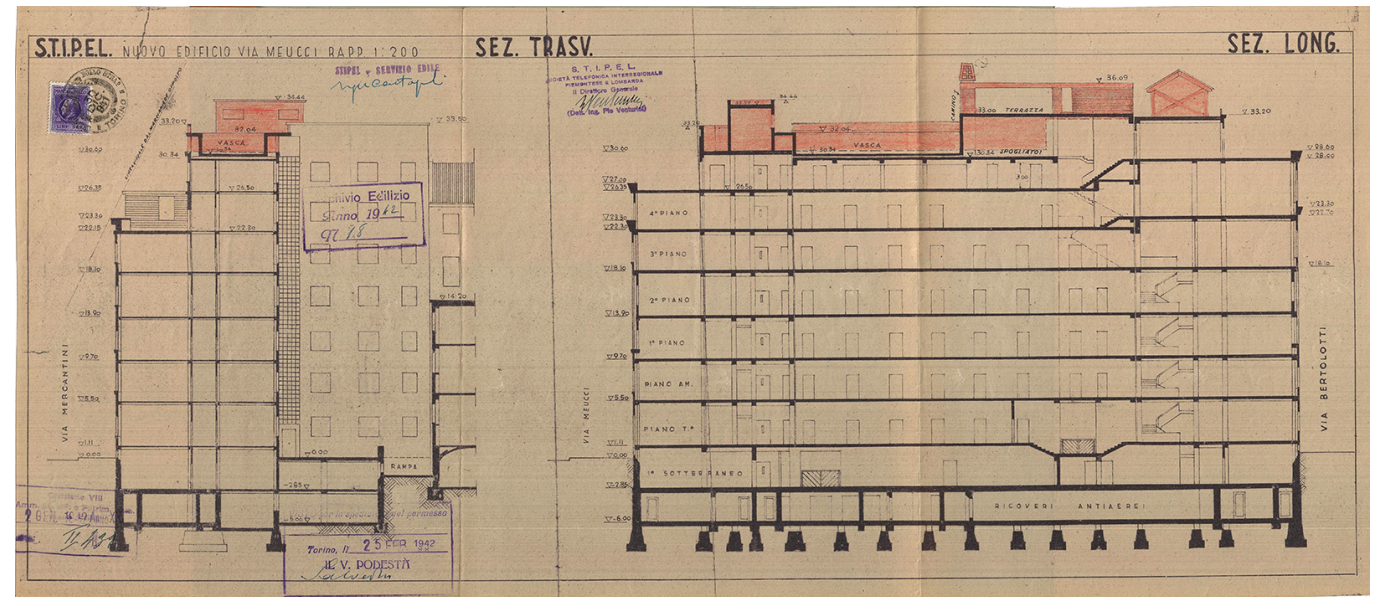


Fig. 7.Vista prospettica esterna dallangolo tra via (elaborato degli autori).
II valore comunicativo del modello è particolarmente evidente anche nella rappresentazione dell'involucro dell'edificio. I prospetti sono infatti articolati su diversi piani paralleli sia alla macro-scala dei volumi della composizione architettonica, sia alla scala di dettaglio dei particolari delle modanature. Tali arretramenti ed aggetti sono inevitabilmente poco comprensibili dai prospetti originali, in quanto disegni bidimensionali. La rappresentazione tridimensionale degli esterni, ottenute dal modello, sono invece molto efficaci nel mostrare tali articolazioni volumetriche e di dettaglio (fig. 7).

Più in generale poi, la produzione di viste prospettiche è uno strumento di comunicazione che permette la divulgazione della conoscenza del manufatto architettonico ad un pubblico più ampio [6]. II ricorso alla rappresentazione grafica bidimensionale è una pratica comune in ambito professionale dettata dalla necessità di trasmissione dei dati dimensionali. Essa costituisce però un linguaggio tecnico, la cui intellegibilità richiede la conoscenza dei metodi

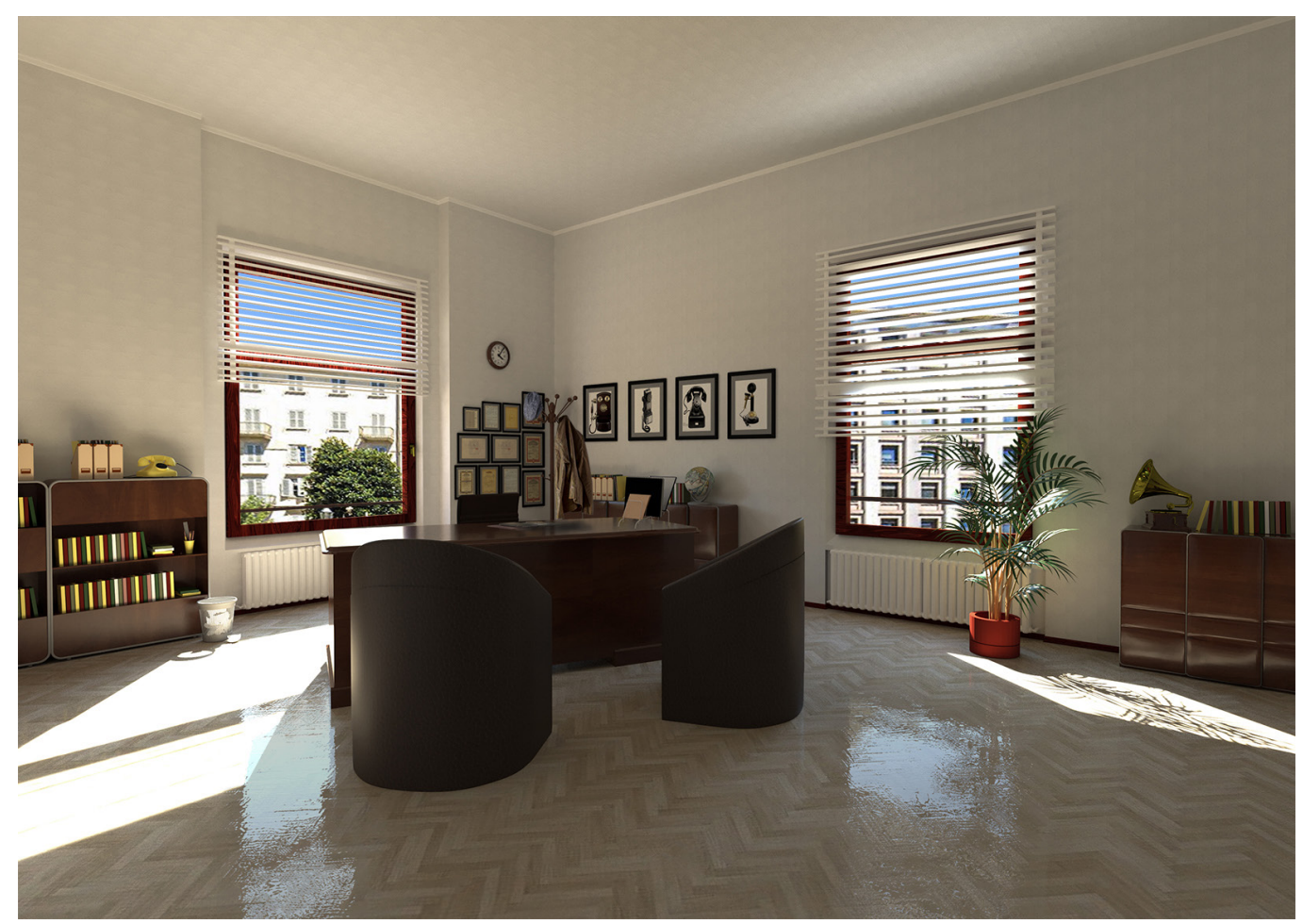

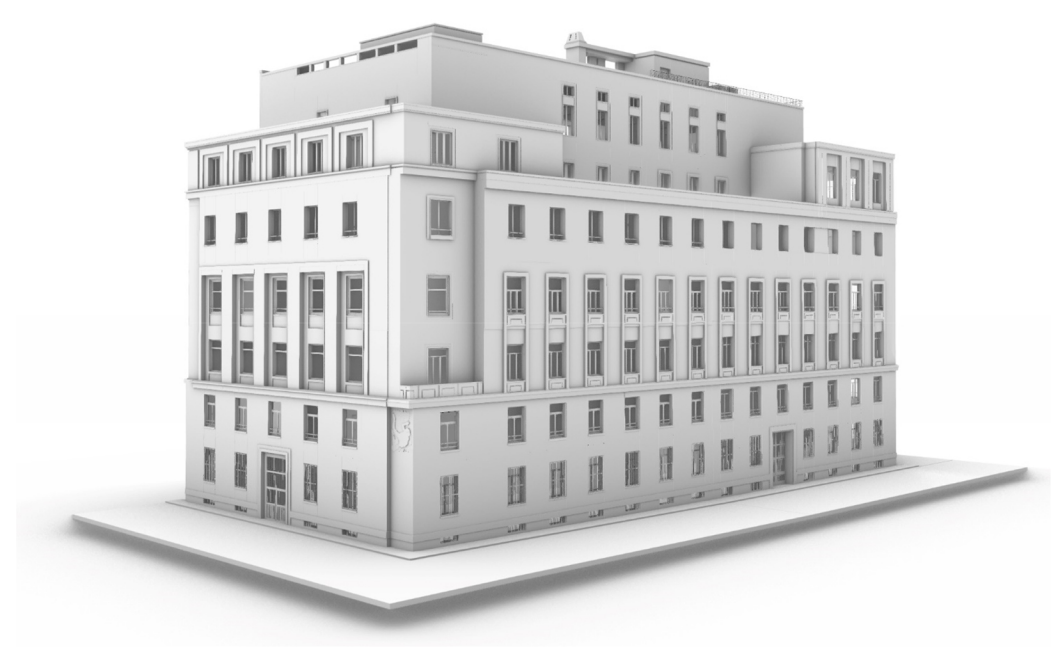

Fig. 8. Render di un ufficio d'angolo (elaborato di A. Mungo, K. Polyakov, A Sabbatini, S. Stein). 
Figg. 9, 10. Render dei collegamenti orizzontali e verticali (elaborato di A. Mungo, K. Polyakov, A Sabbatini, S. Stein).
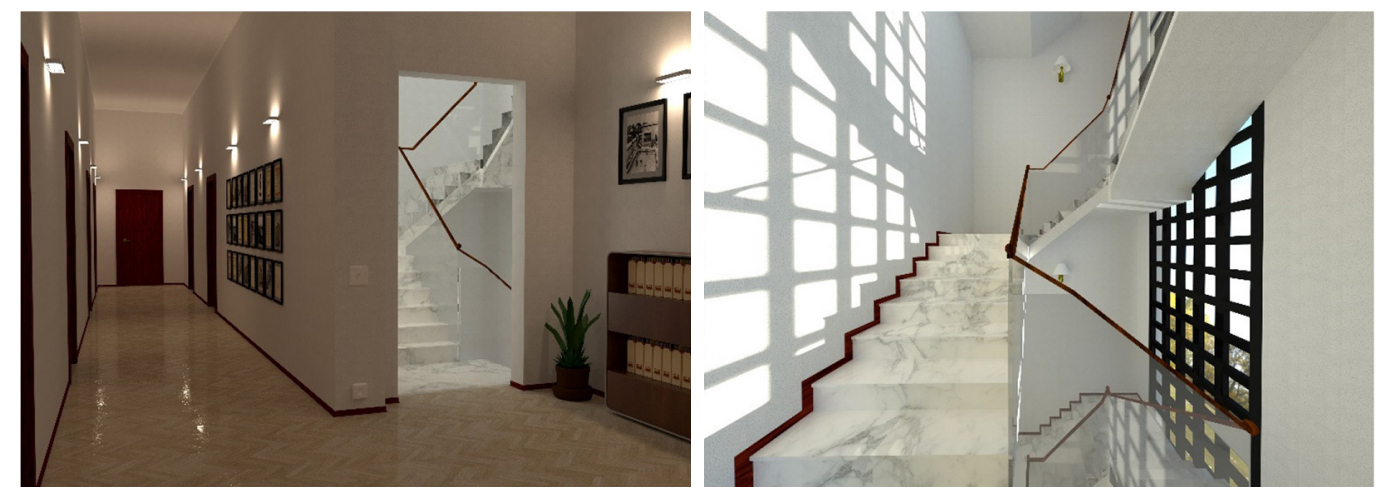

e delle regole della scienza della rappresentazione, e pertanto non è facilmente comprensibile ad un pubblico di non esperti. La rappresentazione prospettica invece emula la visione umana ed è, per questo motivo, di immediata comprensione per chiunque. II suo utilizzo migliora l'accessibilità e la fruibilità della conoscenza del patrimonio storico-monumentale che costituisce un bene comune.

II modello tridimensionale, manipolato con appositi software di rendering, permette anche lo studio della luce all'interno e all'esterno dell'edificio consentendo quindi di approfondire il suo ruolo nel progetto architettonico. Si possono infatti ri-creare ed analizzare gli effetti di chiaro-scuro, dovuti alle ombre proprie e portare, che si vanno a generare sull'involucro dell'edificio sia a causa della sua conformazione volumetrica articolata su vari piani paralleli, sia a causa degli aggetti ed arretramenti delle modanature. In aggiunta possono essere indagati i livelli di luminosità ed i diversi effetti che la luce naturale crea nelle varie tipologie di ambienti dell'edificio come gli uffici (fig. 8), i corridoi, le scale (figg. 9, I0), etc.

II modello digitale, inoltre, consente di ricostituire virtualmente l'unità potenziale dell'edificio [Brandi 1963, pp. I3-20], che oggi non è più percepibile, a causa delle superfetazioni che si sono susseguite nel tempo. In particolare, la copertura dell'edificio ospitava la piscina per i dipendenti della compagnia telefonica, che oggi non è più presente ed ha lasciato spazio alle dotazioni impiantistiche resesi necessarie nel tempo. Tale ambito costituiva una delle parti più affascinanti ed innovative del progetto, oltre a rappresentare una chiara testimonianza storica della sensibilità che si era sviluppata all'epoca circa il benessere dei dipendenti di un'azienda. II modello sviluppato a partire dai disegni originali dell'arch. Castagnoli permette di riportare alla luce questi spazi (figg. II, I2) e di ricomporre la loro relazione con il resto dell'edificio, fornendo al fruitore una visione organica del progetto originale (fig. I 3).

Sul piano dell'accessibilità, il modello digitale apre ad importanti ed innovative possibilità. Come ulteriore sviluppo della ricerca, infatti, gli elaborati grafici ottenuti o addirittura l'intero modello 3D navigabile, potrebbero essere resi disponibili in rete, permettendone potenzialmente a chiunque l'accesso. Uno studio sui modelli digitali per applicazioni mobili, riporta, ad esempio, iVisit3D come un'utile applicazione che genera visite virtuali tramite immagini statiche e viste panoramiche predeterminate [Barazzetti 20I5, p. 39]. Ciò consentirebbe a tutti una visita virtuale all'edificio che, per quanto profondamente diversa da una visita reale,
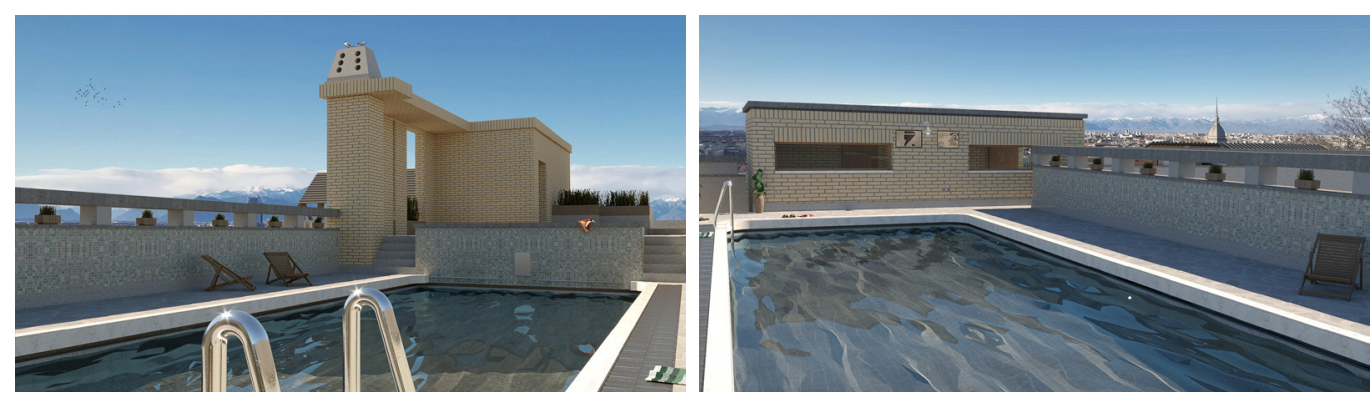

Fig. I I. Render della piscina pensile (elaborato di A. Amadio, A. Fichera,

Fig. 12. Render della piscina pensile con il panorama torinese sullo sfondo (elaborato di A Amadio, A. Fichera, F. Presentati, M. Primiano). 
Fig. 13. Vista prospettica a volo d'uccello dell'edificio: in evidenza la copertura con la piscina pensile $5 \times 15 \mathrm{~m}$, profonda $1.5 \mathrm{~m}$ (elaborato degli autori).

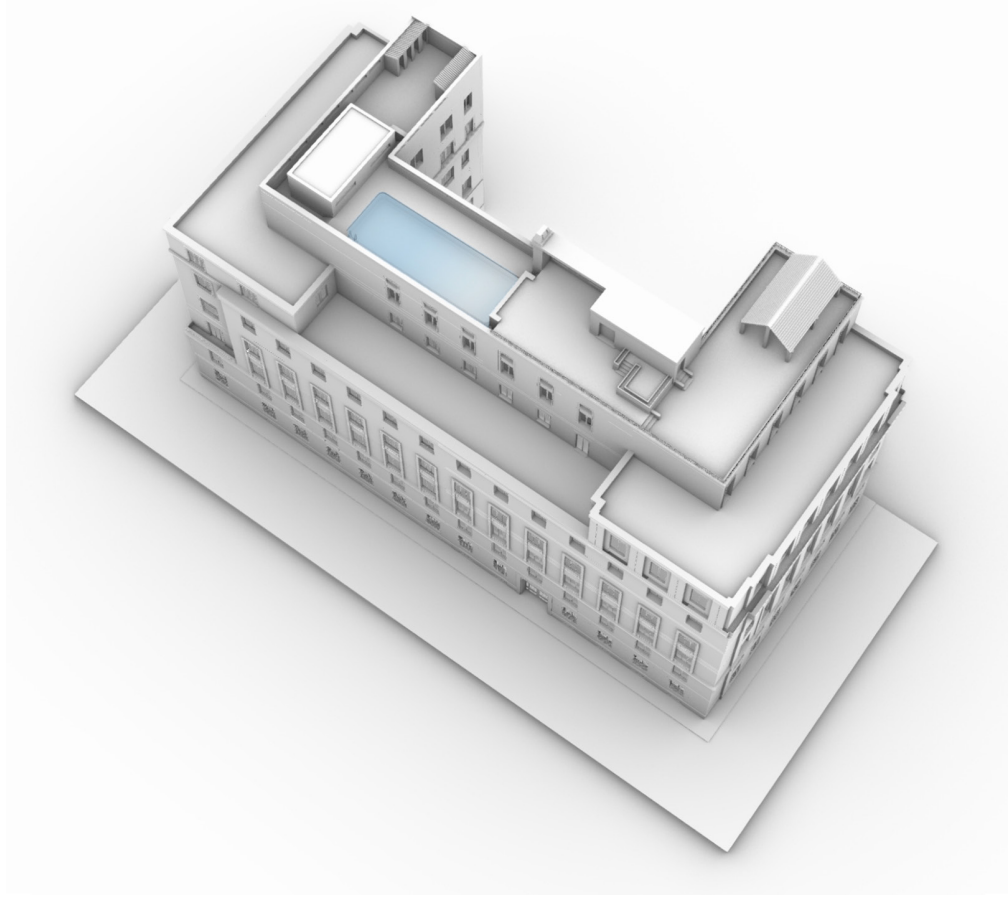

è in grado di aumentare il livello di conoscenza in modo significativo. L'implementazione di un tale sistema consentirebbe l'accesso, seppur virtuale, agli interni dell'edificio che oggi non sono visitabili in quanto sede degli uffici di un'azienda privata. Inoltre il modello virtuale in rete permetterebbe la fruizione dell'opera a chiunque da qualsiasi parte del mondo, senza la necessità di spostarsi, ampliando quindi il pubblico a cui si rende disponibile. Tale implementazione del modello risulta poi particolarmente vantaggiosa nel momento storico attuale, qualora le limitazioni agli spostamenti e l'accesso ai luoghi della cultura dovuti alla pandemia da COVID-19 dovessero protrarsi ancora a lungo. (G.M.).

\section{Conclusioni}

Le testimonianze di una ricca corrispondenza tra Ubaldo Castagnoli e Luigi Einaudi hanno inizio nel 1947 e sono oggi conservate presso l'Archivio della Fondazione Einaudi. II copioso numero di documenti, lettere e biglietti, alcuni scritti a mano, attestano un lungo e fecondo rapporto tra il professionista e l'Uomo di Stato che scrive su carta intestata degli Enti in cui è figura di primissimo piano:Vicepresidente del Consiglio dei Ministri, Ministro del Bilancio, Governatore della Banca d'Italia. Dal 1948, anno della sua nomina a Presidente della Repubblica, i contatti proseguono su carta semplice con la scritta a stampa "Luigi Einaudi" in alto a sinistra e timbro postale del Quirinale. Durante quegli anni Castagnoli curerà il recupero della casa di famiglia in via Lamarmora 80 a Torino, pesantemente lesionata dai bombardamenti, e i lavori di ristrutturazione di villa San Giacomo nella campagna piemontese a Dogliani. Nello scorrere dei testi inerenti il podere si intravede lo spessore del rapporto tra il progettista e il suo illustre committente che propone o risponde puntualmente con considerazioni progettuali di carattere visivo o fruitivo. Architetto per lunghi anni del Presidente della Repubblica in carica, Ubaldo Castagnoli, progettista della ardita piscina pensile a 32 metri di altezza, è indubbiamente una figura sfuggita alla critica forse in ragione del suo stile riservato e del ruolo direttivo in una delle più rilevanti aziende del Paese. Lo studio dei suoi disegni e dei documenti di archivio, alla luce dello specifico disciplinare del disegno - analisi grafica e modellazione - possono indubbiamente costituire un contributo alla comprensione della sua figura di professionista operoso non solo nell'ambito dell'architettura per le telecomunicazioni. (M.I.). 


\section{Note}

[I] Su alcune note biografiche e l'analisi di alcuni progetti si veda [Velo 2020].

[2] 1936: inizia l'ampliamento dell'edificio su via Confienza; Gennaio 1939: progetto nuova sede con variante (annullato) ad esclusione del piano I sotterraneo; Aprile-Dicembre 1939: secondo progetto (planimetria, 9 piante, 3 prospetti e 2 sezioni del dicembre); Luglio 1940, primo progetto piscina (poi annullato); 1941: progetto rialzo via Confienza; Gennaio I94I, rialzo di un piano (annullato); Febbraio 1942: secondo progetto piscina; 1943: esecutivo facciate via Meucci; 1950: progetto rialzo via Confienza, progetto per laboratori sotterranei via Meucci. In Archivio EdificaTO, Ricerca e consultazione delle pratiche di edilizia privata.

[3] Parte delle strutture potrebbero oggi essere coperte dagli impianti collocati sul tetto.

[4] II gruppo di ricerca, attraverso i contributi dei diversi componenti che si sono succeduti nel tempo, ha sperimentato le potenzialità del modello digitale ricostruttivo su temi storici: rilievi di architetture monumentali (a titolo di esempio si veda [Incerti 2016]) e moderni [Incerti 2016]. Su questo ampio e fecondo filone di ricerca si vedano i lavori dell'Università di Bologna tra cui il recente [Frommel 2020].

[5] Corso di Tecniche di Rappresentazione dell'Architettura, Dipartimento di Architettura di Ferrara, A.A. 2020-21 .

[6] Per le prime ricerche su questo tema si veda [Migliari 2008].

\section{Riferimenti bibliografici}

Barazzetti L. et al. (20I5). HBIM and augmented information: towards a wider user community of image and range-based reconstructions. In Yen Y. N., Weng K. H., Cheng H.M. (a cura di). The International Archives of the Photogrammetry, Remote Sensing and Spatial Information Sciences. Atti del 25th International CIPA Symposium 20 I 5. Taipei (Taiwan), 3I August - 4 September 2015, vol. XL-5/W7, p. 39. Copernicus Pubblications.

Brandi C. (2000). Teoria del restauro. Torino: Einaudi.

Castagnoli U., Frette. G (1934). Nuovo Negozio della sartoria Spagnolini S.A. in via Manzoni 7 a Milano. In Edilizia Moderna 14,1934 .

Del Debbio E. (1933). Piscine. Roma: Palombi.

Donghi D. (1923). Manuale dell'architetto. 2.1.1: La composizione architettonica: distribuzione; abitazioni civili, edifıci religiosi, edifici per istituti di educazione, edifici di conforto, stabilimenti balneari, edifici per il servizio postale, telegrafico e telefonico. Torino: UTET.

Frommel S. et al. (2020). Alcune ipotesi di ricostruzione del progetto di Leonardo per il tiburio del duomo di Milano utilizzando modelli digitali 3D. In SCIRES, n. IO (I), pp. 53-66.

Hevko I. et al. (2020). Methods building and printing 3D models historical architectural objects. In SHS Web of Conferences. In The international Conference on History, Theory and Methodology of Learning, vol. 75, 04016.

Incerti M. (2016). Le ville del concorso della IV Triennale di Monza (1930). Disegno e modello nella comunicazione del progetto. Prefazione di Emma Mandelli; contributi di Matteo Cassani Simonetti e Uliva Velo; including an english summary. Bologna: Bononia University Press.

Incerti M., lurilli S. (2016). Rilievo, modello e comunicazione multimediale: dalla didattica alla ricerca. In Perea Echevarría E., Castaño Valiente E. (a cura di). El arquitecto, de la tradición al siglo XXl: docencia e investigación en expresión gráfica arquitectónica. XVI Congreso Internacional de Expresión Gráfica Arquitectónica. Alcalà de Henares: Fundación General de la Universidad de Alcalá, vol. I, pp. 35।-360.

Migliari R. (2008). Prospettiva dinamica interattiva. La tecnologia dei videogiochi per l'esplorazione dei modelli 3D di architettura. Roma: Edizioni Kappa.

Velo U., Castagnoli A., Incerti M. (2020). Ubaldo Castagnoli. Dal Gruppo 7 alle architetture per le telecomunicazioni/Ubaldo Castagnoli. From Gruppo 7 to architectures for telecommunications. In Arena A. et al. (a cura di). Connettere. Un disegno per annodare e tessere. Atti del $42^{\circ}$ Convegno Internazionale dei Docenti delle Discipline della Rappresentazione/Connecting. Drawing for weaving relationships. Proceedings of the 42th International Conference of Representation Disciplines Teachers, pp. 2869-2890. Milano: FrancoAngeli.

Autori

Manuela Incerti, Università degli Studi di Ferrara, icm@unife.it Gianmarco Mei, Università degli Studi di Ferrara, gianmarco.mei@unife.it Anna Castagnoli, illustratrice, anna.castagnoli@gmail.com

Per citare questo capitolo: Incerti Manuela, Mei Gianmarco, Castagnoli Anna (2021). Ubaldo Castagnoli e la piscina pensile del Palazzo dei Telefoni di Torino/Ubaldo Castagnoli and the Hanging Swimming Pool of the Palazzo dei Telefoni in Turin. In Arena A. Arena M. Mediati D. Raffa P. (a cura di). Connettere Un disegno per annodare e tessere Linguagoi Distanze Tecnologie. Atti del $42^{\circ}$ Convegno Internazionale dei Docenti delle Discipline dello Rappresentazione/Connecting. Drawing for weaving relationship. Languages Distances Technologies. Proceedings of the 42 th International Conference of Representation Disciplines Teachers. Milano: FrancoAngeli, pp. 2367-2384. 


\title{
Ubaldo Castagnoli and the Hanging Swimming Pool of the Palazzo dei Telefoni in Turin
}

\author{
Manuela Incerti \\ Gianmarco Mei \\ Anna Castagnoli
}

\section{Abstract}

In the early forties, an open air swimming pool was inaugurated on the last floor of the new STIPEL building as a place of leisure for the employees of the telephone company. The designer was Ubaldo Castagnoli, a young architect-engineer and founder -together with Luigi Figini, Gino Pollini, Guido Frette, Sebastiano Larco, Carlo Enrico Rava, Giuseppe Terragni- of the Gruppo 7.Through the analysis of unpublished archival drawings and digital modelling, we continue the work of investigation on this figure who has yet to be adequately studied.

\section{Keywords}

Gruppo 7, swimming pools, archival drawings, digital reconstructions, Ubaldo Castagnoli.

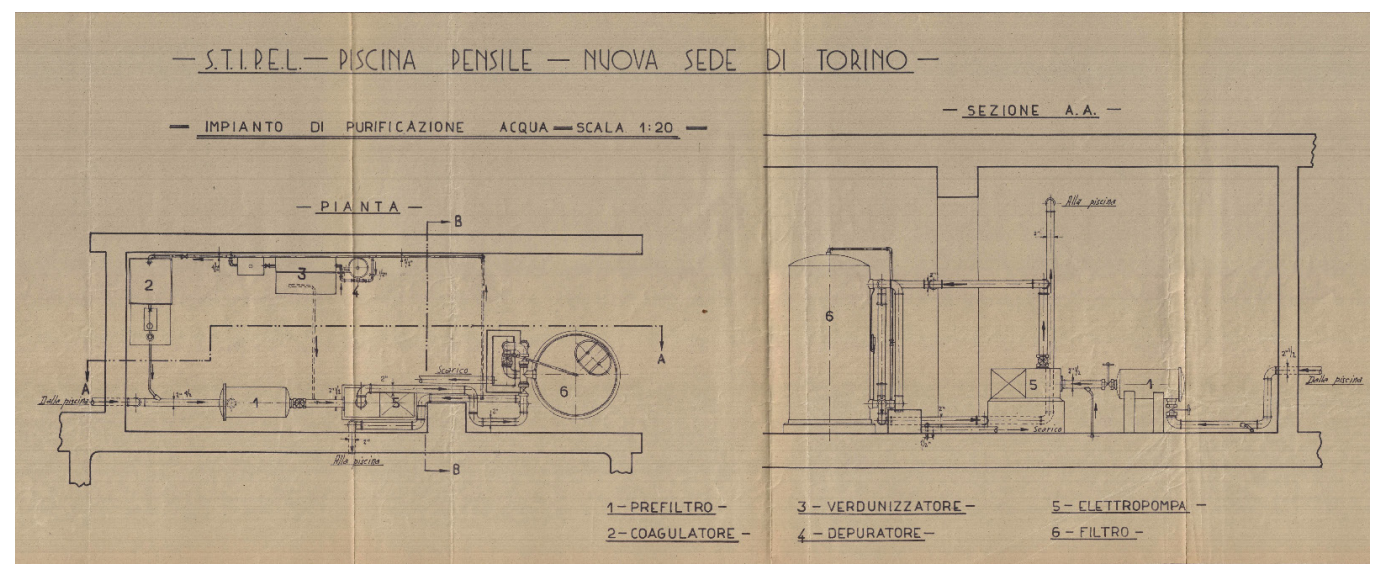




\section{Historical notes}

Ubaldo Castagnoli (Rome 1902 - Turin 1982) graduated in 1925 at the Regio Istituto tecnico superiore of Milan, where he meets the six young colleagues of Gruppo 7. It is known that his participation in the group was of short duration and he was soon replaced by Adalberto Libera.

From 1927 until the early thirties, Castagnoli shared a studio with Guido Frette in Milan,Via Rugabella 9. As a member of the Interprovincial Order of Lombardy and of the Architects of Milan (29/09/1928), he designed, together with Frette, a grave for the Jewish Cemetery of Milan [1 929, Archivio Figini-Pollini, MART, fig. Pol.3. I.2.2] and a shop for the Sartoria Spagnolini in via Manzoni 7, Milan (fig. I). The collaboration with Frette stopped due to his hiring at the Telephone Company, STIPEL. He worked as a designer of power plants and telephonic facilities in the Piedmont and Lombardy area until 1957. Because of some health issues, he continued to collaborate with STIPEL for seven more years as a freelancer [I]. (A.C.).

\section{The telephone building and its history}

From 1925, the block confined by the roads Antonio Meucci, Luigi Mercantini, Davide Bertolotti and Confienza, housed the offices STIPEL, concessionaire of the telephone service for the area of Piedmont and Lombardy. The archives of the Municipality of Turin help us reconstruct some key-events that led to the raising of the historical building and the new addition on Via Meucci. The fundamental steps took place between 1936 and 1950 and were always directed by Architect Castagnoli.

The increasing need for space initially led to a request of an extension on the side of via Confienza (1936). At the beginning of 1939 it resulted in the project of a new building on Via Meucci, which was subjected to some variations (fig. 2) until 1943 [2]. During the years of World War 2, numerous air raids often lashed Turin, hitting the 'Palazzo dei Telefoni' several times between November 1942 and August 1943.

In this difficult wartime period, the project for the new building was born with seven floors and two basement levels, including the air raid shelter, of 6I,40x28x 5 m. In July 1940, the first project for a rooftop swimming pool was presented, flowingly subjected to variation in 1942. Of great interest are the drawings in which Castagnoli deals with the composition

Fig. I. Design of the furniture for the tailor's shop. Unsigned paper and therefore not uniquely the two authors. Both the two authors. Both perspectives with this cute perspectives with this cut view [Castagne point of (Castagnoli, Frette

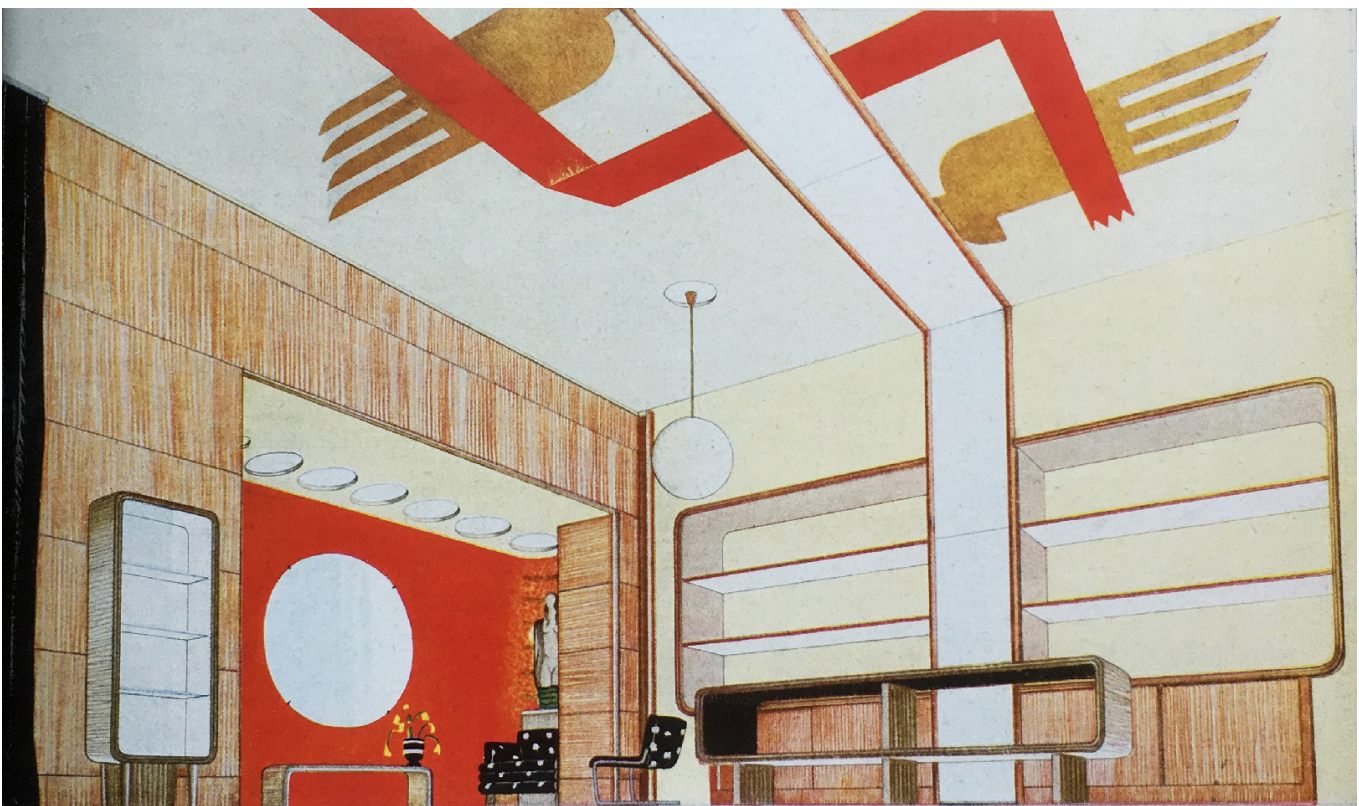


Fig. 2. On the left the building dating back to 1925 , on the right the original building with the raising and the addition on via Meucci, both designed by Castagnoli (on the right Archivio Storico Tim).
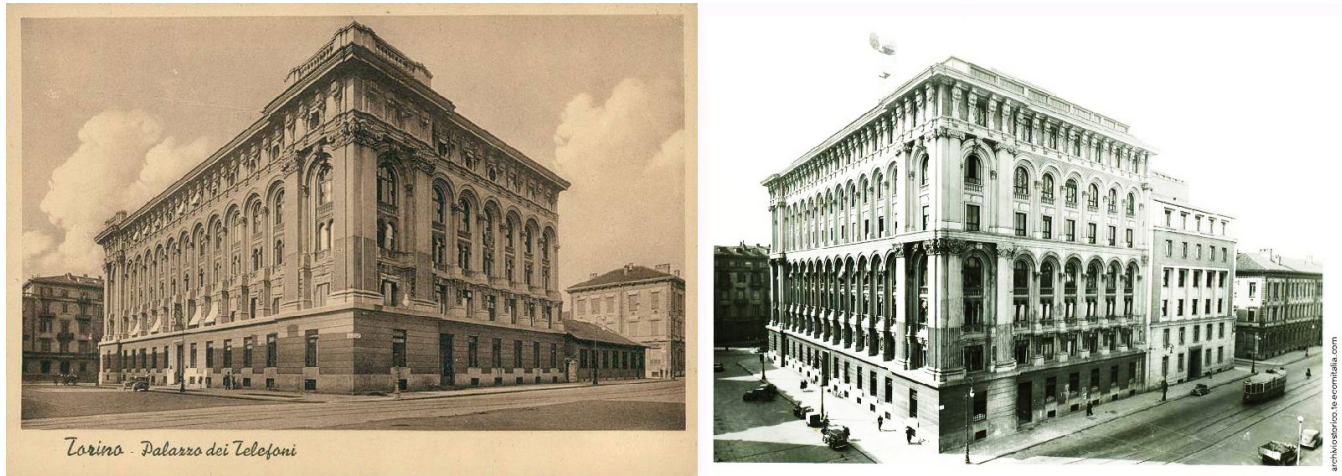

issue between the two blocks: the existing building clearly characterized by important historical type details, and his new building, marked by clear lines and rigorous geometry (fig. 3). His design approach, respectful of historical forms, is clearly intelligible in his drawing of 1950, which shows the project of the raising of the building on via Confienza, which is meticulously matched with the height of the new swimming pool. (M.I.).

\section{The hanging swimming pool}

The project papers for the rooftop pool of the new building, presented in February 1942, replaced the drawings of 1940.

The project was clearly very innovative from both a social point of view (the spaces where destined to the STIPEL employees for their leisure after working hours) as well as from an architectural point of view.

Just a few years earlier, Enrico del Debbio had published a beautiful volume titled Piscine [Del Debbio 1933], in which he described the most interesting and important international projects for pools, divided by typologies and uses and with graphic and photographic materials. In the book, rooftop pools are completely missing and the ones that are not

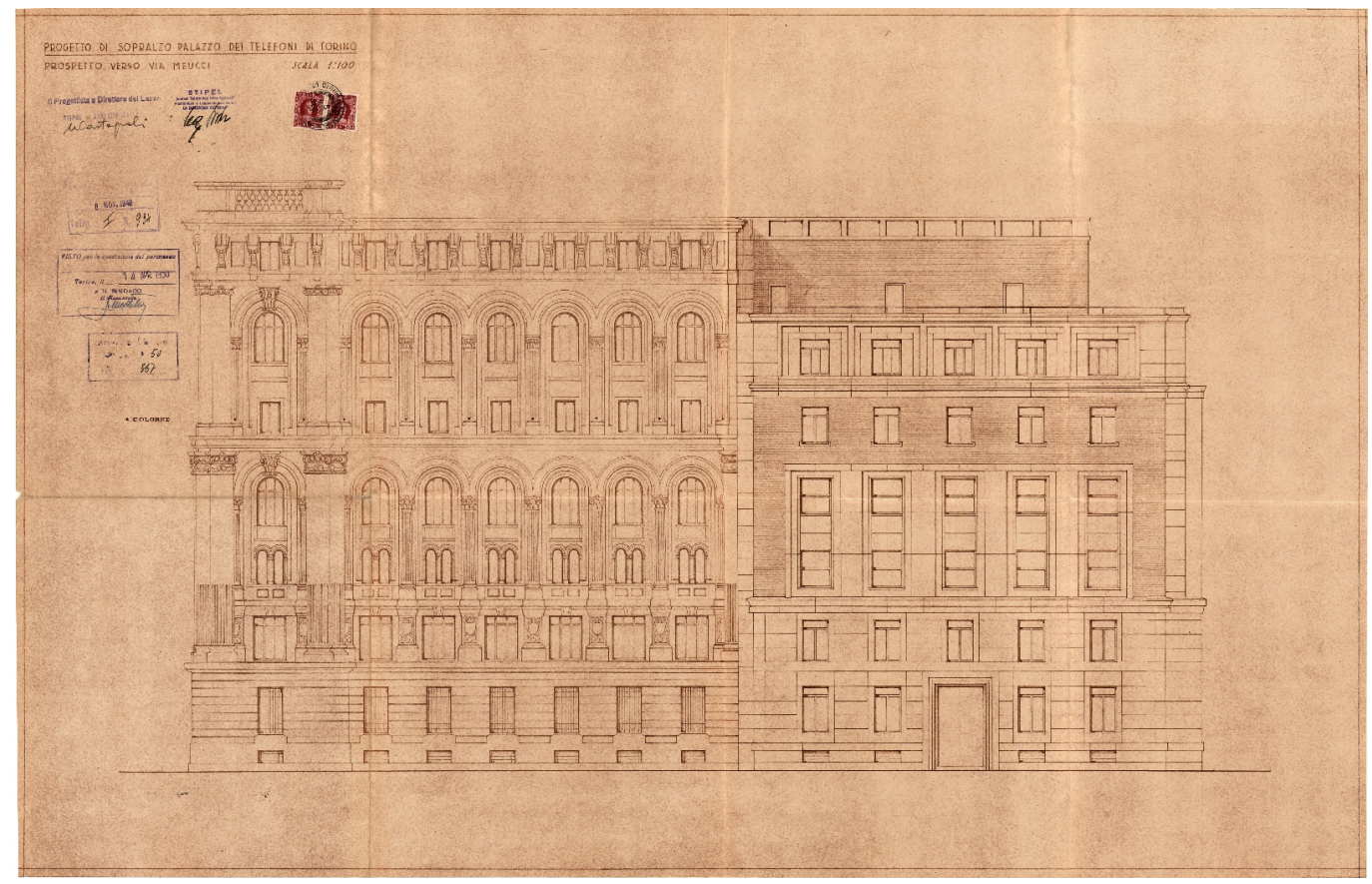


"grounded" are very few. Another possible source available to Castagnoli was the Manuale dell'Architetto by Donghi [Donghi 1923], which, despite discussing this design topic in dozens of pages, holds few references to pools placed at a certain height from the ground with an external 'air chamber'. Therefore, Castagnoli's idea was original (for the small and shallow pool of Le Corbusier on the rooftop of the Unite d'Abitation of Marseille, one must wait until the fifties): a pool at 32 meters from the ground with an outstanding view on the landscape ofTurin (fig. 4).

As for the Central facility of Città Studi of Milan [Velo 2020], the cladding of the pool is carefully designed with horizontal and vertical layers of rectangular tiles. His project also includes the construction drawings of the plumbing, the water filtration system and the description of the corridor for the inspection of the suspended pool, titled "hanging pool" (fig. 5).

To complete the investigation on the form and on the perceptual aspects of the fruition of this space, that today is no longer in use [3], we used digital three-dimensional reconstruction, re-drawing the project of the entire building. This is a widely consolidated method in the scientific disciplinary sector, previously explored by the research group for its value both as a study tool and as an opportunity to enhance and disseminate knowledge on architectural projects that were never built or were destroyed due to events over time [4]. (M.I.).

\section{The digital 3D model}

As an integral part of the path towards knowing the Palazzo dei telefoni, a digital model has been built starting from the original drawings.

The model was created with a NURBS surface modelling software in an educational environment [5].The modelling process is a useful investigation and analysis tool. The techniques of 3D modelling of an object include two main phases: the analytical phase (collection of the basic material, calculation of the dimensions and parameters) and the purely modelling phase [Hevko 2020, p. 2]. The three-dimensional reproduction requires spatial understand-

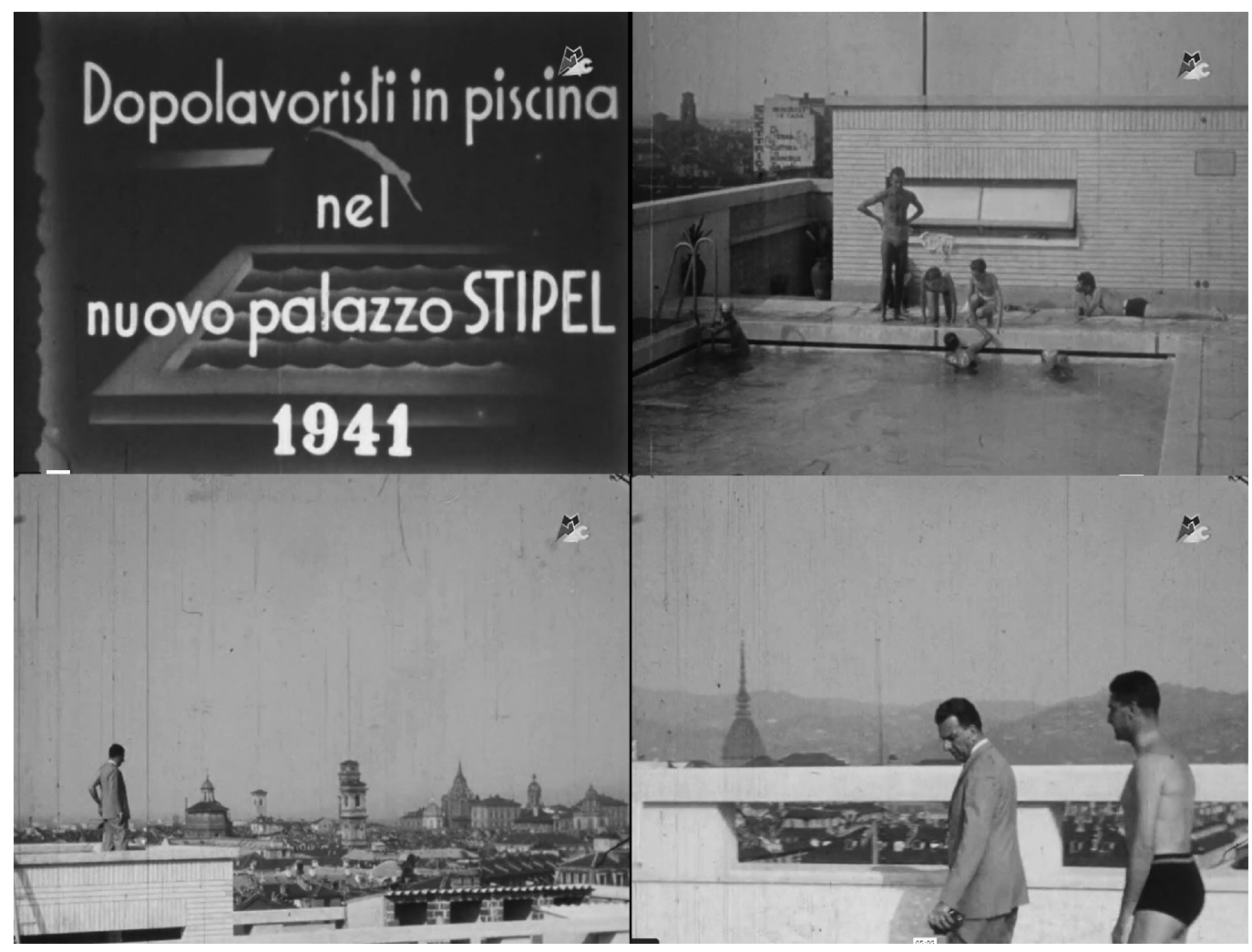


Fig. 5. Work by the architect Castagnoli Hanging swimming poo 1942 (EdificaTO Archive)

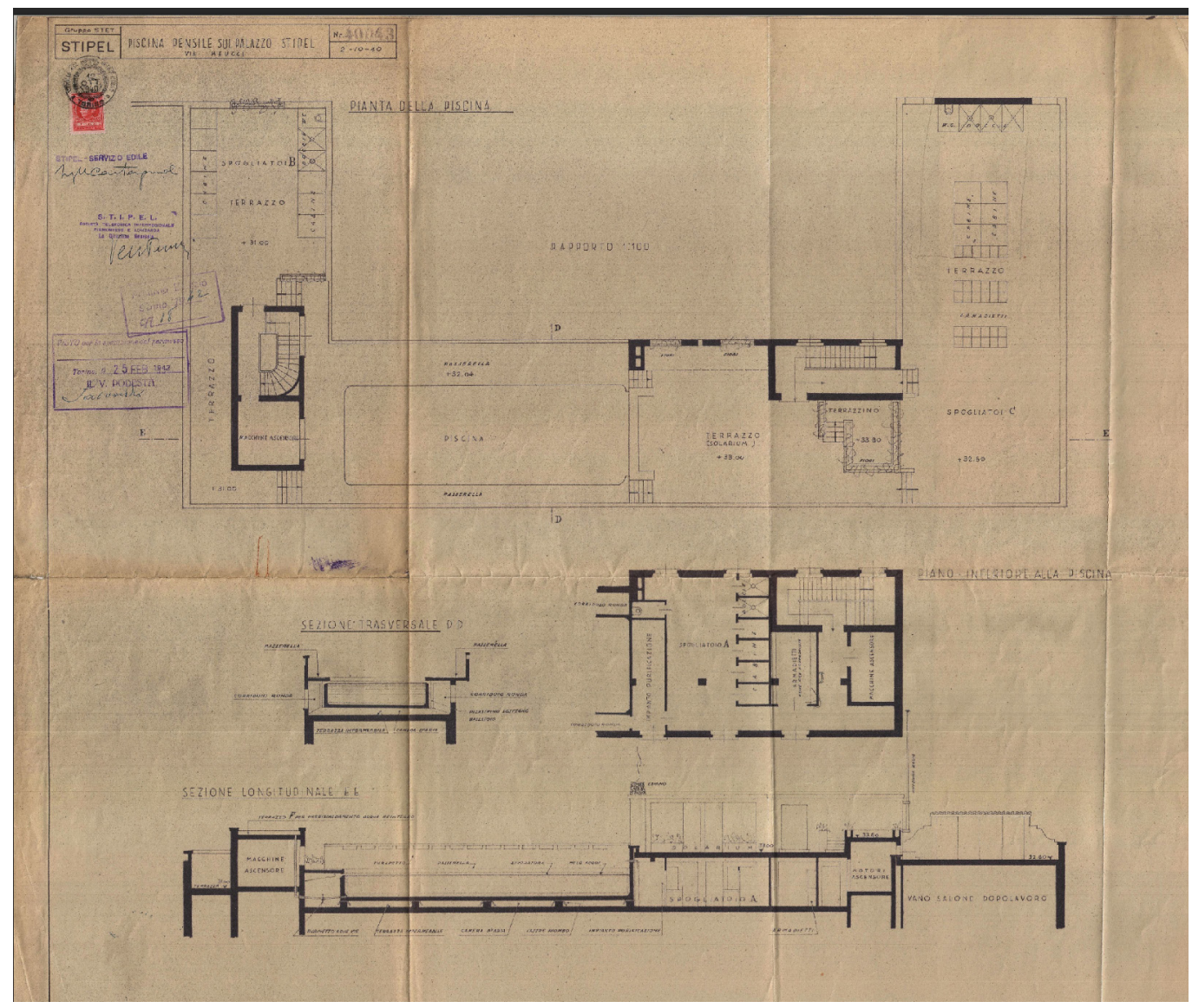

ing of even the most complex parts of the building, such as the top floors where double volumes and variable floor heights follow one another. The morphology of these environments is not immediately evident from the original drawings (fig. 6), and the modelling implies the creation of an object that collects all the geometric and dimensional information available from different two-dimensional drawings in a coherent way. The model obtained is thus an important communication tool since it allows the creation of documents capable of effectively showing these articulations (fig. 7).

The communicative value of the model is also particularly evident in the representation of the envelope of the building. The elevations are in fact articulated on different parallel

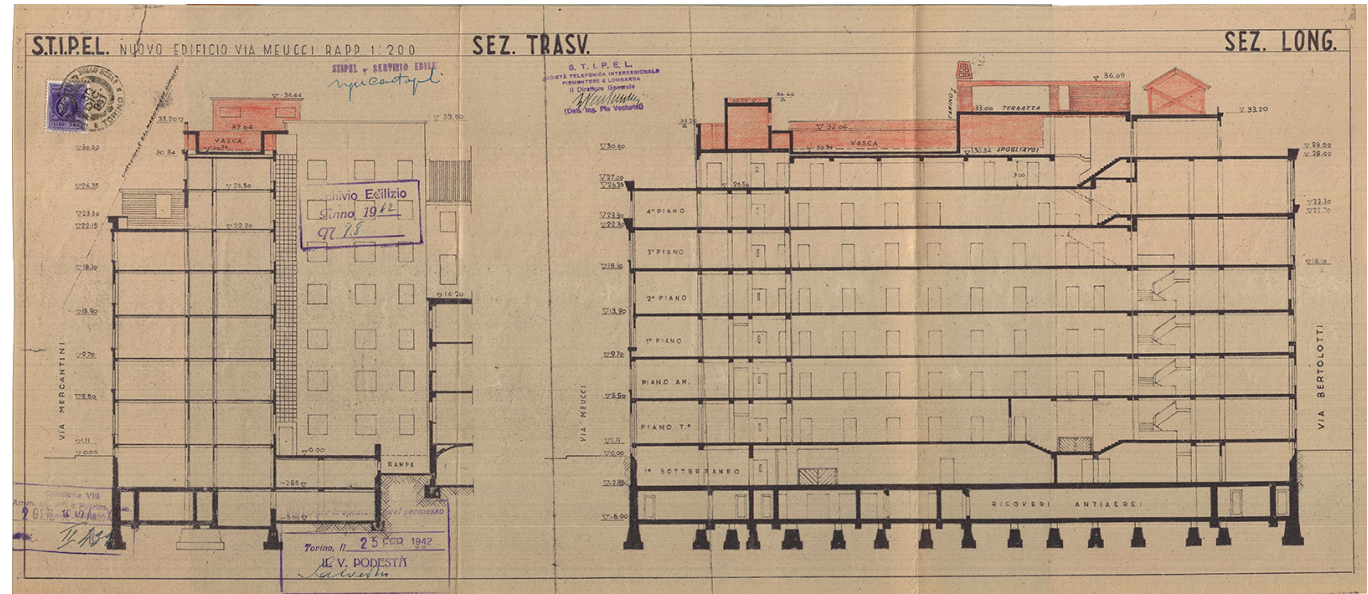


Fig. 7. External perspective view from the corner between via Meucci and via Confienza (by the authors).

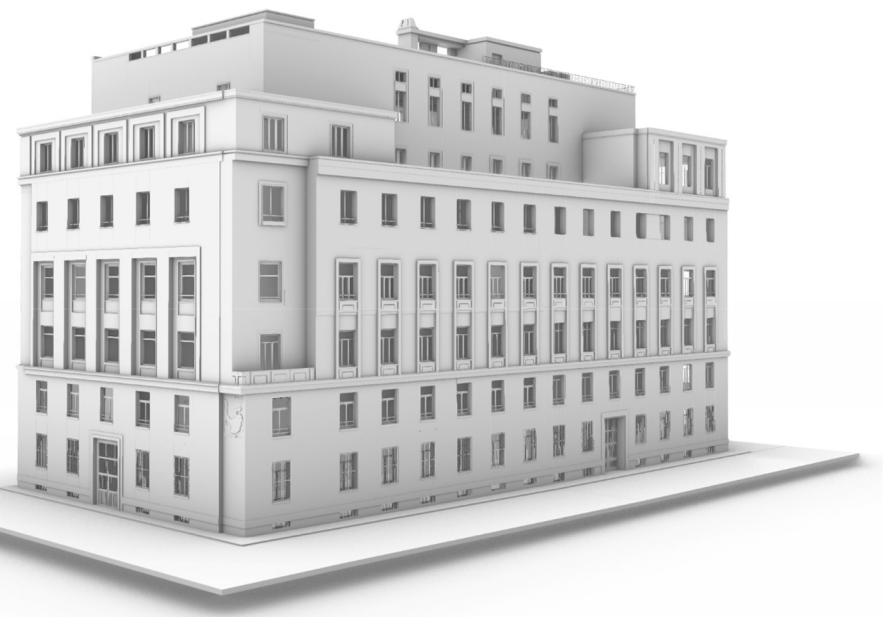

planes: both on the macro-scale of the volumes of the architectural composition, and on the detailed scale of the geometry of the mouldings. These are inevitably hard to understand from the original elevations, as they are two-dimensional drawings. The three-dimensional representation of the exterior obtained from the model is instead very effective in showing these volumetric and detailed articulations (fig. 7).

More generally, the production of perspective views is a communication tool that allows the dissemination of knowledge of the architectural artefact to a wider audience [6]. The use of two-dimensional graphic representation is a common practice in the professional field dictated by the need for communication of dimensional data. However, it constitutes a technical language, whose intelligibility requires the knowledge of methods and rules of the representation science, and therefore it is not easily understandable to a non-expert public. The perspective representation, on the other hand, emulates the human vision and is

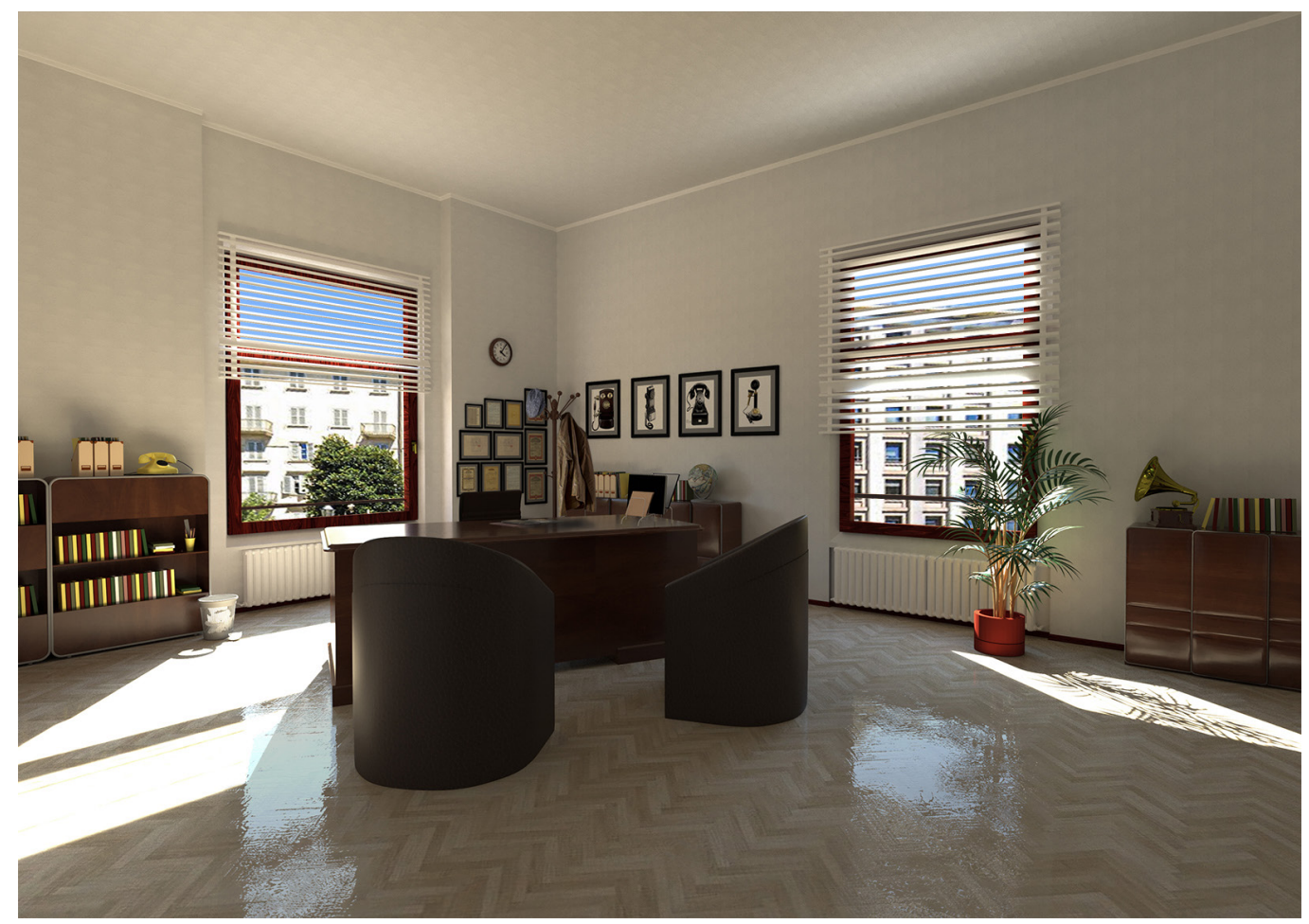

Fig. 8. Render of a corner office (by A. Mungo, K. Polyakov, A. Sabbatini, S. Stein) 
Figs. 9, 10. Render of horizontal and vertical connections (by A. Mungo, K. Polyakov, A Sabbatini, S. Stein).
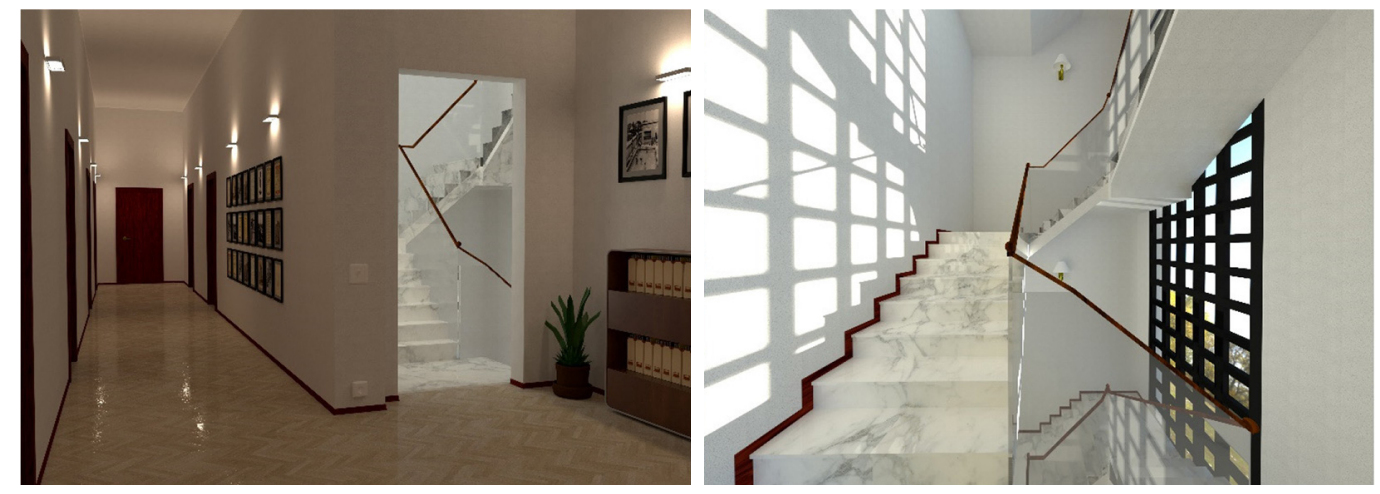

therefore easily understood by anyone. Its use improves the accessibility and usability of the knowledge of the historical-monumental heritage, a shared good.

The three-dimensional model, manipulated with proper rendering software, also allows the study of light inside and outside the building, thus permitting us to deepen its role in the architectural project. It is possible to re-create and analyse the chiaro-scuro effects (from its own and delivered shadows) generated on the building envelope, both because of its volumetric conformation articulated on various parallel floors, and because of cantilevers and setbacks of the mouldings. In addition, the levels of brightness and the different effects that natural light creates in the various types of environments such as offices (fig. 8), corridors, stairs (figs. 9, 10), etc. can be investigated.

The digital model also allows us to virtually reconstitute the potential unity of the building [Brandi 1963, pp. 13-20], which today is no longer perceivable due to the changes that have occurred over time. In particular, the roof of the building that housed the swimming pool for the employees of the telephone company is no longer present. It is now used to house the systems' equipment that has become necessary over time. This area was one of the most fascinating and innovative parts of the project, as well as clear historical proof of the sensitivity that had developed for the well-being of the company's employees at the time. The model developed from Castagnoli's original drawings allows us to bring these spaces back to light (figs. II, I2) and to recompose their relationship with the rest of the building, providing the observer with an organic view of the original project (fig. 13).

In terms of accessibility, the digital model opens up important and innovative possibilities. For further development of the research, the graphic drawings obtained or even the entire navigable 3D model could be made available online, potentially allowing access to anyone. A study on digital models for mobile applications reports, for example, iVisit3D as a useful application that generates virtual visits through static images and predetermined panoramic views [Barazzetti 20I5, p. 39]. This would allow everyone to virtually visit the building. Although this is profoundly different from a real visit, it would lead to a considerable level of knowledge and understanding. The implementation of such a system would allow access, albeit virtual, to the interior of the building, which today cannot be
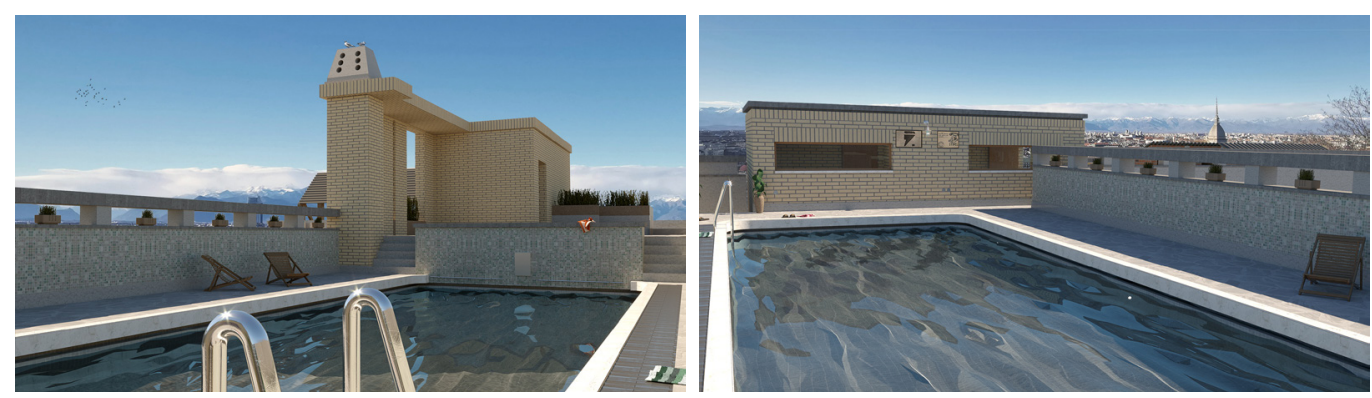

Fig. II. Render of the Amadio, A. Fichera, F. Presentati, M. Primiano).

Fig. 12. Render of the rooftop pool with the Turin panorama in the background (by A. Amadio, A. Fichera, F Presentati, M. Primiano). 


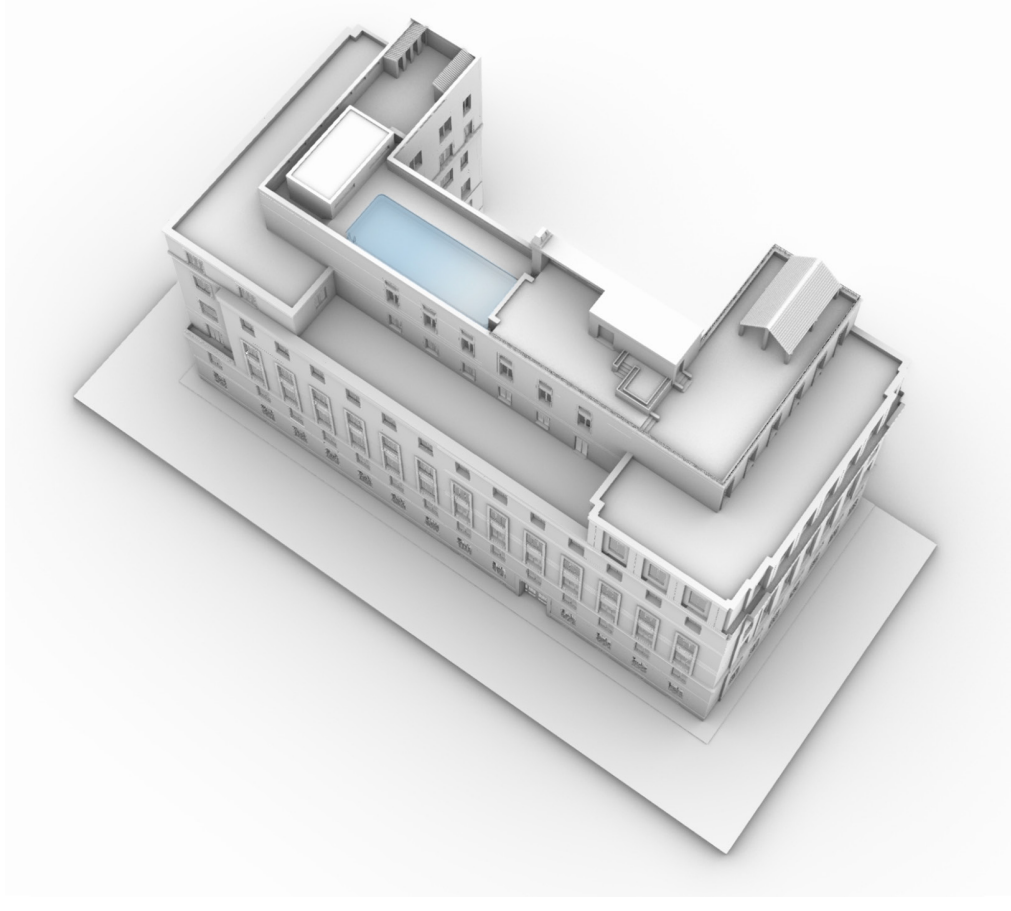

visited as it houses the offices of a private company. In addition, the virtual model on the internet would allow anyone from anywhere in the world to enjoy the building without the need to move, thus expanding the public to which it is available. This implementation of the model is also particularly advantageous in the current historical period, given the limitations to travel and access to cultural facilities due to the ongoing COVID-19 pandemic. (G.M.).

\section{Conclusions}

The records of a rich correspondence between Ubaldo Castagnoli and Luigi Einaudi began in 1947 and are now preserved in the Archive of the Einaudi Foundation. The copious number of documents, letters and cards, some written by hand, show a long and fruitful relationship between the professional and the State Man, who wrote on the headed paper of the Bodies for which he was a leading figure:Vice President of the Council of Ministers, Minister of the Budget, Governor of the Bank of Italy. Since 1948, the year of his appointment as President of the Republic, communication continued on plain paper with the printed word "Luigi Einaudi" in the upper left corner and postmarked by the Quirinale. During those years, Castagnoli had taken care of the recovery of the family home in via Lamarmora 80, in Turin, heavily damaged by the bombings, and the renovation works of Villa San Giacomo in the Piedmontese countryside in Dogliani. In the texts concerning the villa, one can glimpse the depth of the relationship between the designer and his illustrious client, who proposed or responded promptly with design considerations about visual and usability issues. Ubaldo Castagnoli, Architect of the President of the Republic in office for many years and designer of the daring swimming pool hanging 32 meters above the ground, is undoubtedly a figure that went unnoticed by criticism, perhaps because of his discreet style and his managerial role in one of the most important companies in the Country. The study of his drawings and archival documents in the specific field of the architectural drawing -graphic analysis and modelling-can certainly make a valuable contribution to the understanding of his figure as a professional, not only in the field of architecture for telecommunications. (M.I.). 


\section{Notes}

[1] On some biographical notes and the analysis of some projects, see [Velo 2020]

[2] 1936: the expansion of the building begins on via Confienza; January 1939: project of a new building with variant (cancelled) with the exception of floor I underground;April-December 1939: second project (plan, 9 plans, 3 elevations and 2 sections of December); July 1940, first swimming pool project (later cancelled); 194 I: project to raise the building on via Confienza; January 1941: project for a one-floor addition (cancelled); February 1942: second swimming pool project; 1943: detailed drawing of facades on via Meucci; 1950: project for the addition on via Confienza, project for underground laboratories on via Meucci. In the EdificaTO Archive, Research and consultation of private building practices.

[3] Part of the structures could now be covered by the systems placed on the roof.

[4] The research group, through the contributions of various components that have followed one another over time, has experimented the potential of the digital reconstructive model on historical themes: survey of monumental architecture (for example, see [Incerti 20 16]) and modern ones [Incerti 2016]. On this broad and fruitful line of research, see the works of the University of Bologna including the recent [Frommel 2020].

[5] Course in Techniques of Architectural Representation, Department of Architecture of Ferrara, Academic Year 2020-2I.

[6] For the first research on this topic, see [Migliari 2008].

\section{References}

Barazzetti L. et al. (20I5). HBIM and augmented information: towards a wider user community of image and range-based reconstructions. In Yen Y. N., Weng K. H., Cheng H.M. (a cura di). The International Archives of the Photogrammetry, Remote Sensing and Spatial Information Sciences. Atti del 25th International CIPA Symposium 20 I 5. Taipei (Taiwan), 3I August - 4 September 20।5, vol. XL-5/W7, p. 39. Copernicus Pubblications.

Brandi C. (2000). Teoria del restauro. Torino: Einaudi.

Castagnoli U., Frette. G (1934). Nuovo Negozio della sartoria Spagnolini S.A. in via Manzoni 7 a Milano. In Edilizia Moderna 14,1934 .

Del Debbio E. (1933). Piscine. Roma: Palombi.

Donghi D. (1923). Manuale dell'architetto. 2.1.1: La composizione architettonica: distribuzione; abitazioni civili, edifıci religiosi, edifici per istituti di educazione, edifici di conforto, stabilimenti balneari, edifici per il servizio postale, telegrafico e telefonico. Torino: UTET.

Frommel S. et al. (2020). Alcune ipotesi di ricostruzione del progetto di Leonardo per il tiburio del duomo di Milano utilizzando modelli digitali 3D. In SCIRES, n. IO (I), pp. 53-66.

Hevko I. et al. (2020). Methods building and printing 3D models historical architectural objects. In SHS Web of Conferences. In The international Conference on History, Theory and Methodology of Learning, vol. 75, 04016.

Incerti M. (2016). Le ville del concorso della IV Triennale di Monza (1930). Disegno e modello nella comunicazione del progetto. Prefazione di Emma Mandelli; contributi di Matteo Cassani Simonetti e Uliva Velo; including an english summary. Bologna: Bononia University Press.

Incerti M., lurilli S. (2016). Rilievo, modello e comunicazione multimediale: dalla didattica alla ricerca. In Perea Echevarría E., Castaño Valiente E. (a cura di). El arquitecto, de la tradición al siglo XXl: docencia e investigación en expresión gráfica arquitectónica. XVI Congreso Internacional de Expresión Gráfica Arquitectónica. Alcalà de Henares: Fundación General de la Universidad de Alcalá, vol. I, pp. 35।-360.

Migliari R. (2008). Prospettiva dinamica interattiva. La tecnologia dei videogiochi per l'esplorazione dei modelli 3D di architettura. Roma: Edizioni Kappa

Velo U., Castagnoli A., Incerti M. (2020). Ubaldo Castagnoli. Dal Gruppo 7 alle architetture per le telecomunicazioni/Ubaldo Castagnoli. From Gruppo 7 to architectures for telecommunications. In Arena A. et al. (a cura di). Connettere. Un disegno per annodare e tessere. Atti del $42^{\circ}$ Convegno Internazionale dei Docenti delle Discipline della Rappresentazione/Connecting. Drawing for weaving relationships. Proceedings of the 42th International Conference of Representation Disciplines Teachers, pp. 2869-2890. Milano: FrancoAngeli.

\section{Authors}

Manuela Incerti, Università degli Studi di Ferrara, icm@unife.it Gianmarco Mei, Università degli Studi di Ferrara, gianmarco.mei@unife.it Anna Castagnoli, illustratrice, anna.castagnoli@gmail.com

To cite this chapter. Incerti Manuela, Mei Gianmarco, Castagnoli Anna (202I). Ubaldo Castagnoli e la piscina pensile del Palazzo dei Telefoni di Torino/Ubaldo Castagnoli and the Hanging Swimming Pool of the Palazzo dei Telefoni in Turin. In Arena A. Arena M. Mediati D. Raffa P. (a cura di). Connettere. Un disegno per annodare e tessere Linguagoi Distanze Tecnologie. Atti del $42^{\circ}$ Convegno Internazionale dei Docenti delle Discipline dell' Rappresentazione/Connecting. Drawing for weaving relationship. Languages Distances Technologies. Proceedings of the 42 th International Conference of Representation Disciplines Teachers. Milano: FrancoAngeli, pp. 2367-2384. 